\title{
The effect of cognitive restructuring counselling technique on reducing students' social media usage intensity
}

\author{
Irwayanti \\ Guidance and Counselling, SMPN 1 Palu, Indonesia \\ Email: irwayanti76@gmail.com \\ Ahmad Yasser \\ Psychology, Universitas Negeri Makassar, Indonesia \\ Email: ahmadyasser_mansyur@yahoo.com
}

(Received: 12-July-2019; Reviewed: 07-August-2019; Accepted: 10-September-2019; published: 26-December-2019)

\begin{abstract}
The purpose of this research is to discover the effect of cognitive restructuring counseling technique on social media usage intensity of SMPN 1 Bantaeng students. This research uses quantitative approach with Quasi Experimental Design with the Nonequivalent Control Group Design research design. The subjects of this research were 20 students in class VIII who were identified as having high social media usage intensity. The data collection techniques used in this research are usage intensity scaling, observation, and interviews. The results of this research discovers that the implementation of cognitive restructuring technique can reduce the intensity of social media usage intensity as applied according to the procedures that have been designed through 8 meetings. The intensity of using social media before implementing cognitive restructuring technique was considered high but after implementing cognitive restructuring technique, the intensity of using social media decreased.
\end{abstract}

Keywords: Cognitive Restructuring Techniques; Counselling Techniques; Social Media; Student.

\begin{abstract}
Abstrak: Tujuan dari penelitian ini adalah untuk mengetahui apakah teknik restrukturisasi kognitif berpengaruh terhadap intensitas penggunaan media sosial siswa di SMPN 1 Bantaeng. Pendekatan yang digunakan dalam penelitian ini adalah pendekatan kuantitatif dengan menggunakan Quasi Eksperimental Design dengan desain penelitian Nonequivalent Control Group Design. Subjek penelitian ini adalah siswa kelas VIII yang berjumlah 20 orang yang teridentifikasi mengalami intensitas penggunan media sosial yang tinggi. Teknik pengumpulan data yang menggunakan skala intensitas penggunaan media sosial, observasi dan wawancara. Hasil penelitian ini menunjukkan bahwa pelaksanaan teknik restrukturisasi kognitif dapat menurunkan intensitas penggunaan media sosial dilaksanakan sesuai dengan prosedur yang sudah dirancang intensitas penggunaan media sosial sesudah penerapan teknik restrukturisasi kognitif, berada pada kategori rendah terlihat intensitas durasi $>2$ jam per hari, kategori frekuensinya $>7$ kali per hari, dan menurunnya hubungan pertemanan di media sosial.
\end{abstract}

Kata kunci: Teknik Restrukturisasi Kognitif; Teknik Konseling; Media Sosial; Siswa. 


\section{INTRODUCTION}

Information technology such as internet, which has many applications namely social media, is a media where the users could gain information, communicate, and build relations online (Persada, Hafina, \& Nurhudayah, 2017). They also stated that by using social media, people could easily create a group where individuals could communicate and share opinions to each other. This would make it easier for people to communicate and discuss about various topics and cases. People could also make assumptions, build emotions and trust through comments or point of views of the others on social media.

The number of internet users, especially in social media platforms, increased in 2018. According to an annual digital report released by We Are Social and Hootsuite Lubis (2018), the growth of social media of the year reached the number of $13 \%$ with the total users of 3 billion people. The Indonesian Internet Provider Association or famously known as Asosiasi Penyelenggara Jasa Internet Indonesia (APJII, 2018) stated that 143,26 million people of Indonesian population nowadays could access the internet. $49,52 \%$ of the said number are from the young people. Internet users in Indonesia sorted based on age are as follows: $16,68 \%$ are of age $12-18,49,52 \%$ are of age $19-34,29,55 \%$ are of age $35-54$, and $4,24 \%$ are of above 54 years of age. This means that the number of internet users is dominated by teenagers.

According to the pre-survey using interview method on 25 students in eight grade, it is showed that there are 10 students who had very high social media usage intensity; they were engaged with addiction to the point they lost track of time and abandoned their duties, including works and school tasks. There are also 8 students who had high intensity on using social media such as Facebook, WhatsApp, Twitter, Youtube, and Line. The result of the interview shows that the average amount of time used by these 25 students to access social media is $\geq 2$ hours/day and the average frequency of accessing or updating social media on various platforms is $\geq 7$ times/day. There are many reasons why students use social media frequently. Buente \& Robin (2010) stated that sometimes the reasons are dysfunctional and disoriented, i.e. (1) Wanting attention from others. According to a study, teenagers like to share information on social media in order to gain attention. (2) Teenagers nowadays tend to ask opinions from their friends on social media when making decision. (3) Building persona. Social media is actually unable to describe someone thoroughly. Therefore, teenagers use social media to build their own positive persona. Teenager tends to show positive image on social media in hope the other people would see him/her the way she/he wants them to. (4) Teenagers think that social media is everything, thus, not using social media is considered as outdated.

Triantoro (2013) explained that the most harmful effect of social media for users is losing the track of time which caused the high usage intensity. This phenomenon also happens to students, ranging from elementary school students to college students. Most of them have social media accounts. Their fondness of social media often leads them to be unproductive and abandon their duties and responsibilities as students (Zha et al., 2018; Dwivedi et al., 2018; Sutcliffe et al., 2018).

The phenomenon happening nowadays is the students' addiction to social media (Kircaburun et al., 2018; Sahin, 2018; Turel, 2018). Many students are so engaged with their smartphones that they use 24 hours to browse and explore cyberspace continuously. This surely affects the students' focus and learning outcome. These two things could not be gained effortlessly but by efforts. Therefore, if students are addicted to social media, their learning compentence would be decreased.

The problem regarding social media usage intensity happened on students need to be solved with the help of guidance and counselling teachers. The teachers need to help those who have high intensity of using social media. The help may take different forms, such as responsive service. Responsive service is the immediate help for the students who are in urgent need. If the students are not given immediate help, there is possibility it would lead to certain problems since addiction to gadgets might ruin children's social interaction development. This happens because children are habituated with the excitement they get from one-way interaction with gadget instead of playing with their friends.

This will lead to their lack of social skills (Mozee, 2012; Cahyono, 2016; Putri, 2017; Sari \& Ayiani, 2018). One of the counselling techniques that could be used to reduce social media usage intensity is cognitive restructuring technique. Young (2010) stated that cognitive restructuring counselling approach is effective in 
solving the problem regarding high social media usage intensity. Cognitive restructuring technique is able to help students to change their irrational mindset of using social media $\geq 2$ hours a day and accessing $\geq 7$ times a day into more rational mindset when using social media. Rizky (2013) conducted a research to test the effectivity of cognitive restructuring technique to develop self-positivity of SMAN 2 Sidoarjo students. The research found that there is significant progress on the self-positivity of the subjects. This means that cognitive restructuring strategy is effective in helping students to develop their self-positivity.

Cognitive restructuring technique is also effective in helping people to think more positively so they could reduce the feelings (Chioma, Elizabeth, \& Ersol, 2016; Jinghan, et al., 2018; Pardo \& Calero, 2019; Hasibuan, Purwanto, \& Japar, 2018; Chandra, Wibowo, \& Sunawan, 2019). To reduce social media usage intensity of junior high school students, a particular approach is needed to open and improve their mindset. Cognitive restructuring technique is the precise approach. Therefore, it is expected that after the application of this technique the social media usage intensity of the junior high school students could be reduced. Bryant et al. (2009) stated in his research that cognitive restructuring technique could improve an individual's mindset. Mitchell \& Krumboltz (2010) also stated in their research that cognitive restructuring is more effective and helpful in decision-making. Debra et al. (2010) explained that cognitive restructuring technique consists of five steps: (1) Identification of the cognitive errors which famously known as Automatic Thoughts (ATs), (2) Identification of cognitive distortions on ATs, (3) Rational debate about AT with Socrates' method, and (4) The development of rational rebuttal to ATs.

Prior researches about cognitive restructuring that had been conducted focused on students' tendency of online game addiction and WhatsApp usage (Mensah, 2016; Trisnani, 2017; Pratiwi, Andayani, \& Karyanta, 2012; Rahmi, 2015). The result stated that cognitive restructuring technique was used to reduce the tendency of online game and smartphone addiction on teenagers which caused them to harm their surroundings, become apathetic, and mostly focus on their smartphones. Unlike those prior researches, this research is focused on students' social media usage intensity: the duration of using social media and the frequency of accessing, checking, and using social media facilities in a day.

\section{METHOD}

This study is a quantitative research with experimental approach. As for the design of the experiment itself is the Quasi Experimental Design in the form of non-equivalent control group design. In this research, there are two variables: cognitive restructuring technique and students' social media usage intensity. 1) Cognitive Restructuring is one of counselling techniques that aims to build more adaptable or suitable mindset. Cognitive restructuring helps counselees to think differently and change their basic and fallacious mindset with more rational, realistic, and positive mindset. 2) Social media usage intensity is the profundity and intensity level of using social media facilities as seen in duration (in hours) and frequency (in a day) used as scales.

The research population in this study is the students in their eighth grade according to 2018/2019 academic year. The total number of the students listed was 186 . These students were identified as having problem related to their high social media usage intensity ( $\geq 2$ hours/day in duration and $\geq 3$ times/day in frequency).

Table 1. Distribution of the Research Population

\begin{tabular}{cccc}
\hline No. & Class & Total Students & Identified Students \\
\hline 1. & VIII A & 32 & 9 \\
2. & VIII B & 29 & 7 \\
3. & VIII C & 31 & 8 \\
4. & VIII D & 31 & 8 \\
5. & VIII E & 32 & 5 \\
6. & VIII F & 31 & 5 \\
\hline \multicolumn{2}{c}{ Total Number } & 186 & 40 \\
\hline
\end{tabular}


The sampling technique used in this research is purposive sampling. The number of the sample is 20 . The collected data is analyzed using descriptive statistics technique and inferential statistics. Non Parametric Wilcoxon Signed Ranks Test $(Z)$ analysis taken from pretest and post-test is used to test examine the hypothesis. Descriptive analysis used to describe the social media usage intensity level before and after pre-test is in the form of cognitive restructuring technique. For this purpose, a frequency distribution table is made with a presentation using quantitative descriptive analysis with frequency distribution and percentage using the formula as follows.

\section{RESULTS AND DISCUSSION}

Students' social media usage intensity level through quantitative approach with experimental research type is affected by cognitive restructuring technique and there is significant change on the experimental group after the application of cognitive restructuring technique.

Table 2. Social Media Usage Intensity Level of SMPN 1 Bantaeng Students in Experimental Group.

\begin{tabular}{cccccc}
\hline \multirow{2}{*}{ Interval } & \multirow{2}{*}{ Category } & \multicolumn{2}{c}{ Pre-test } & \multicolumn{2}{c}{ Post-test } \\
\cline { 3 - 6 } & & $\mathrm{F}$ & $\mathrm{P}(\%)$ & $\mathrm{F}$ & $\mathrm{P}(\%)$ \\
\hline $214-250$ & Very High & 3 & 30 & 0 & 0 \\
$173-213$ & High & 7 & 70 & 0 & 0 \\
$132-172$ & Moderate & 0 & 0 & 2 & 20 \\
$91-131$ & Low & 0 & 0 & 7 & 70 \\
$50-90$ & Very Low & 0 & 0 & 1 & 10 \\
\hline & & 10 & 100 & 10 & 100 \\
\hline
\end{tabular}

Table 2 shows that students' social media usage intensity level is very high before the application of cognitive restructuring technique. Students accessed social media $\geq 2$ hours/day in duration with average frequency of $\geq 7$ times accessing or updating various social media in a day but not for positive purpose, such as academic group discussion on WhatsApp. After the technique was applied within six meetings, the usage intensity was reduced significantly from very high category to moderate category as seen from the duration: $>2$ hours/day and the frequency $>7$ times/day accessing and using social media facilities moderately. Besides, the reduction can also be seen from the online relations which were lowered from high category to low category and the tendency level of using social media is also reduced. From the descriptive statistics analysis result, it could be concluded that students' social media usage intensity level was reduced significantly after the application of cognitive restructuring technique. The measurement of students' social media usage intensity level on control group taken from pretest result was done along with that of experimental group.

The result of pre-test and post-test, in which control group was not given cognitive restructuring was given information service regarding social media usage instead, is shown in this following table of frequency distribution and percentage according to research data.

Table 3. Social Media Usage Intensity Level of SMPN 1 Bantaeng Students in Control Group.

\begin{tabular}{cccccc}
\hline \multirow{2}{*}{ Interval } & \multirow{2}{*}{ Category } & \multicolumn{2}{c}{ Pre-test } & \multicolumn{2}{c}{ Post-test } \\
\cline { 3 - 6 } & & $\mathrm{F}$ & $\mathrm{P}(\%)$ & $\mathrm{F}$ & $\mathrm{P}(\%)$ \\
\hline $214-250$ & Very High & 4 & 40 & 3 & 30 \\
$173-213$ & High & 6 & 60 & 7 & 70 \\
$132-172$ & Moderate & 0 & 0 & 0 & 0 \\
$91-131$ & Low & 0 & 0 & 0 & 0 \\
$50-90$ & Very Low & 0 & 0 & 0 & 0 \\
\hline & & 10 & 100 & 10 & 100 \\
\hline
\end{tabular}


Facebook, WhatsApp, Instagram, Twitter, Youtube, and Line. 4 respondents $(40 \%)$ were in very high category and 6 respondents $(60 \%)$ were in high category in using social media facilities in term of duration and frequency. However, when the post-test was conducted, there was

no significant change. 3 respondents $(30 \%)$ were in very high category and 7 respondents were in high category. This means that social media usage intensity was still high in term of duration and frequency of using the social media.

The observation to see students' participation level during the application of cognitive restructuring technique shows data result as follows:

Table 4. Data Result Percentage of The Observation of Cognitive Restructuring Technique Implementation in SMPN 1 Bantaeng

\begin{tabular}{|c|c|c|c|c|c|c|c|}
\hline \multirow{2}{*}{ Percentage } & \multirow[t]{2}{*}{ Category } & \multicolumn{6}{|c|}{ Meetings } \\
\hline & & $\mathrm{I}$ & II & III & IV & $\mathrm{V}$ & $\mathrm{VI}$ \\
\hline $80 \%-100 \%$ & Very High & 9 & 9 & 10 & 10 & 10 & 10 \\
\hline $60 \%-79 \%$ & High & 1 & 1 & 0 & 0 & 0 & 0 \\
\hline $40 \%-59 \%$ & Moderate & 0 & 0 & 0 & 0 & 0 & 0 \\
\hline $20 \%-39 \%$ & Low & 0 & 0 & 0 & 0 & 0 & 0 \\
\hline $0 \%-19 \%$ & Very Low & 0 & 0 & 0 & 0 & 0 & 0 \\
\hline Total & & 10 & 10 & 10 & 10 & 10 & 10 \\
\hline
\end{tabular}

To know the effect of cognitive restructuring technique on reducing social media usage intensity of SMPN 1 Bantaeng students requires several steps as follows: a) Data Normality Test, based on data normality test result, there are significance levels of 0,200 on experimental group and 0,200 on control group. Since the significance levels of both variables are above 0,05 , then $\mathrm{H} 0$ is accepted. This means that the data of both experimental group and control group has normal distribution., b) Data Homogeneity Test, the test criteria could be considered homogeneous if the significance level is above 0,05 . The data homogeneity test result shows the number 0,006 or above 0,05 . Therefore, it could be concluded that the data of social media usage intensity on experimental group and control group has homogeneous variants. d) Wilcoxon Test. The hypothesis of this research are that $(\mathrm{H} 1)$ cognitive restructuring technique could reduce social media usage intensity and (Ho) cognitive restructuring technique could not reduce social media usage intensity with the criteria "reject (Ho) if z score $\geq$ $z$ table and accept (H1) if $t$ score $<t$ table".

Tabel 5. Data of Students' Social Media Usage Intensity on Experimental Group

\begin{tabular}{lccccc}
\hline \multicolumn{1}{c}{ Group } & $\mathrm{N}$ & Average & Score Gain & $\mathrm{Z}$ & Asymp. Sig \\
\hline Pre-test & 10 & 145,5 & 65,1 & $-2,934$ & 0,003 \\
Post-test & & 80,4 & & & \\
\hline
\end{tabular}

The calculation result using SPSS 21,0 for Windows through Wilcoxon test shows that there is significant change between average pretest score and average post-test score. The score before the application of cognitive restructuring technique (pre-test) is higher than after the application (post-test). Therefore, it could be concluded that (Ho) which stated that cognitive restructuring technique could not reduce the social media usage intensity in SMPN 1 Bantaeng is rejected and (H1) which stated otherwise is accepted. Therefore, cognitive restructuring technique could reduce the social media usage intensity of SMPN 1 Bantaeng students. The hypothesis test using the gap of score gain mean/average between experimental group and control group shows that cognitive restructuring technique could reduce the social 
media usage intensity of SMPN 1 Bantaeng students. The pre-test and post-test show that in experimental group, there is a change on the subjects while in control group, no significant change on the subjects is found. It means that cognitive restructuring technique could be applied to change the habit of using social media to gain better mindset and thinking.

The result of this research is in accordance with several theories about cognitive restructuring technique proposed by the experts, such as Efrord (2016); Persada, Hafina, \& Nurhudayah (2017); Sholihah (2019) who explained that cognitive restructuring technique is arranged to help reaching better emotional responses by changing habitual appraisal from high frequency to lower frequency. According to that statement, it could be implied that cognitive restructuring technique helps counselees to reach more positive mindset by changing the habit into better and organized one so that they could be out of negative thoughts.

Cognitive restructuring technique aims to identify and oppose irrational and maladaptive thinking. Cognitive restructuring focuses on the attempt to identify and fix cognitive errors or perception of counselee regarding himself and his surroundings (Corey, 2015). The purpose of cognitive restructuring applied on counselee who has high intensity of using social media is to oppose the irrational belief and negative thoughts of the counselee. This is applied by collecting negative assumption data, homework sheet in thinking record, and changing mindset errors regarding social media usage.

The benefit of cognitive restructuring technique on students with high social media intensity is that counselees can distinct and comprehend his disoriented thoughts and feelings, and evaluate their belief with evidences so that they could think more rationally. As explained before, social media usage intensity is the students' addiction to social media to the point they lose track on time and abandon their duty and responsibility as students. This problem regarding social media usage intensity should be handled and solved immediately or else it could be fatal for the students. It might decrease their learning achievement, deprive their sleep which leads to health problems, and it might also affect their learning performance in school.

Cognitive restructuring technique or also known as cognitive reframing is a behavioral technique which is related to cognitive counselling. Cognitive restructuring includes the study on how to think differently, eliminate thinking errors and change them into the more rational, realistic, and perhaps positive ones. Efrord (2016) mentioned that many researches show that cognitive-behavioral counselling in the most effective counselling technique to help solving social anxiety or depression. Cognitive restructuring can help counselee in learning to control the mindset, not only positively but also realistically. Therefore, Werner dan Moulds (2011) explained that one of the methods in this technique is the mood improvement strategy.

According to the descriptive statistics analysis, it could be analyzed that basically there is reduction of social media usage intensity on the experimental group which was treated by cognitive restructuring technique. This could be seen from the students with high social media usage intensity. This happened due to the lack of knowledge regarding the harm of overusing social media. The students tended to use social media secretly with their friends and get influenced easily by the other students and the surroundings. However, after the cognitive restructuring technique was applied on them, their social media usage is reduced and they showed more positive attitude and behavior; they are not easily affected to use social media by their surroundings. Their knowledge regarding the impact of social media usage intensity increases and they remain confident even without social media.

\section{CONCLUSION AND SUGGESTIONS}

The application of cognitive restructuring technique to reduce the social media usage intensity of SMPN 1 Bantaeng students was held in six meetings and two additional meetings for pre-test and post-test. The result shows that the students' social media intensity was lowered from high category to low category after the cognitive restructuring technique was applied. This means that the cognitive restructuring technique is effective to reduce social media usage intensity of students if it is applied according to the procedures. Social media usage intensity after the application of cognitive restructuring technique is on the low category as seen from the duration; $>2$ hours/day, the frequency; $>7$ times/day, and the decreased relations on social media, and the usage of social media facilities.

Regarding the conclusion of the study, the researcher discovered that cognitive 
restructuring technique in guidance and counselling activity is rarely implemented in school although the effect has been proven effective in reducing students' social media usage intensity. Therefore, the researcher suggests that counsellors cooperate with relevant parties to apply the cognitive restructuring technique according to the procedures.

\section{REFERENCES}

APJII. (2018). Pengguna dan Prilaku Internet Indonesia. Bulletin Edisi 23 April.

Bryant, R. A, Moulds, M. L, Guthrie, R. M, Dang, S.T, \& Nixon, R.D.V. (2009). Imaginal Exposure Alone and Imaginal Exposure with Cognitive Restructuring in Treatment of Posttraumatic Stress Disorder. Journal of Consulting and Clinical Psychology, 71(4), 706-712.

Buente, \& Robbin. (2010). Trends, in Internet Information Behavior, 2000 - 2004. Journal of the American Society for Infomation science., 2(4), 89-100.

Cahyono, A. S. (2016). Pengaruh media sosial terhadap perubahan sosial masyarakat di Indonesia. Jurnal Publiciana, 9(1), 140157.

Chandra, E. K., Wibowo, M. E., \& Sunawan, S. (2019). Cognitive Behaviour Group Counseling with Self-Instruction and Cognitive Restructuring Techniques to Improve Students' Self-Confidence. Islamic Guidance and Counseling Journal, 2(1), 11-17.

Chioma, C. A., Elizabeth, O. A.-O., \& Errol, J. P. (2016). The Effect of Pilot Cognitive Restructuring Therapy Intervention on Depression in Female Cancer Patients. Psycgo-Oncology, 25(6), 732-736.

Corey, G. (2015). Teori dan Praktek dari Konseling dan Psikoterapi. Bandung: PT. Refika Aditama.

Debra, A. H., James, A. B., Sarah, A. H., James, D. H., \& Michelle, D. W. (2010). Automatic Thoughts and Cognitive Restructuring in Cognitive Behavioral Group Therapy for Social Anxiety Disorder. Cognitive Therapy and Research, 34(1-12).

Dwivedi, Y. K., Kelly, G., Janssen, M., Rana, N. P., Slade, E. L., \& Clement, M. (2018). Social Media: The good, the bad, and the ugly. Information Systems Frontiers, 20(3), 419-423.
Efrord, B. . (2016). 40 Teknik yang Harus Diketahui Setiap Konselor. Yogyakarta: Pustaka Pelajar.

Hasibuan, M. A., Purwanto, E., \& Japar, M. (2018). Effectiveness of group counseling cognitive behavior therapy cognitive restructuring technique and assertive skill training to improve assertive behavior students. Jurnal Bimbingan Konseling, 7(1), 55-65

Jinghan, H., Wencai, Z., Jianxing, Z., Fei, Y., \& Xiaoyu, Z. (2018). The Brief Intervention Effect of Metaphorical Cognitive Restructuring on Alleviating Mental Distress: A Randomised Controlled Experiment. Applied Psychologi: Health and Well Being, 10(3), 414-433.

Kircaburun, K., Alhabash, S., Tosuntaş, Ş. B., \& Griffiths, M. D. (2018). Uses and gratifications of problematic social media use among university students: A simultaneous examination of the Big Five of personality traits, social media platforms, and social media use motives. International Journal of Mental Health and Addiction, 1-23.

Lubis, E. (2018). Potret Media Sosial Dan Perempuan. Jurnal Parallela, 1(2), 89167.

Mensah, S. O. (2016). The Impact Of Social Media On Students' Academic Performance- A Case of Malaysia Tertiary Institution. International Journal of Education, Learning and Training, 1(1), 217-223.

Mitchell, L. K., \& Krumboltz, J. D. (2010). The Effects of Cognitive Restructuring and Decision-Making Training on Career Indecision. Journal of Counseling and Development, 66(4), 171-174.

Mozee, S. (2012). The Impact of Social Media use on Academic Performance at one Urban University: A Pilot Study. Mississippi Urban Research Center. Journal of Rural and Urban Research, 48(2), 288-381.

Pardo, C. R., \& Calero, E. A. (2019). Applying cognitive restructuring in therapy: The clinical reality in Spain. Psychotherapy Research. 29(2), 198-212.

Persada, G. A., Hafina, A., \& Nurhudayah, N. (2017). Program Konseling Restrukturisasi Kognitif Untuk Mereduksi Kecenderungan Adiksi Game 
Online Pada Remaja. Indonesian Journal of Educational Counseling, 1(1), 79-92

Putri, W. T. (2017). Dampak Penggunaan Social Media secara Berlebihan terhadap Regulasi Diri Anak. Indonesian Journal of Islamic Early Childhood Education, 2(2), 243-250.

Pratiwi, P., Andayani, T., \& Karyanta, N. (2012). Perilaku Adiksi Game Online Ditinjau dari Efikasi Diri Akademik dan Keterampilan Sosial pada Remaja di Surakarta. Ilmiah Psikologi Candrawijaya, 1.

Rahmi, S. (2015). Pengaruh Pendekatan Perilaku Kognitif terhadap Tingkat Penyesuaian Diri Siswa di Kelas VII SMP Negeri 29 Makassar. Psikologi Pendidikan \& Konseling, juni 1.

Rizky, S. (2013). Teknik Restrukturisasi kognitif untuk Menurunkan Keyakinan Irrasional pada Remaja dengan Gangguan Somatisasi. Fakultas Psikologi UMM, Malang.

Sari, D. P., \& Ayiani, Y. I. (2018). Hubungan Keterempilan Sosial dengan Kecenderungan Kecanduan Media Sosial pada Remaja. Jurnal Riset Psikologi, 4.

Sahin, C. (2018). Social Media Addiction ScaleStudent Form: The Reliability and Validity Study. Turkish Online Journal of Educational Technology-TOJET, 17(1), 169-182.

Sutcliffe, A. G., Binder, J. F., \& Dunbar, R. I. (2018). Activity in social media and intimacy in social relationships. Computers in human behavior, 85, 227 235.
Sholihah, A. N. (2019). Restrukturisasi Kognitif dengan Setting Kelompok untuk Mengurangi Kecanduan Online Game Remaja. Jurnal Guidance and Counselling (E-Journal), 6(1), 33-42.

Turel, O., Brevers, D., \& Bechara, A. (2018). Time distortion when users at-risk for social media addiction engage in nonsocial media tasks. Journal of psychiatric research, 97, 84-88.

Trisnani. (2017). Pemanfaatan Whatsapp Sebagai Media Komunikasi Dan Kepuasan Dalam Penyampaian Pesan Dikalangan Tokoh Masyarakat. Jurnal Komunikasi, Media dan Informatika, 6(3), 376-385.

Triantoro, B. (2013). Penerapan Konseling Kelompok Behavioral Dengan Teknik Self Management Untuk Mengurangi Kecanduan Facebook Pada Siswa Kelas VIII C SMP Negri 2 Nganjuk. Jurnal BK Unesa, 4(1), 210-220.

Werner, S., A., \& Moulds, M. L. (2011). Mood Repair and Processing Mode in Depression. AS: American Psychological Association.

Young, K. (2010). Cognitive Behaviour Therapy with Internet Addicts: Treatment Outcomes and Implications. Cyber Psychology \& Behavior, 10(5), 673-673.

Zha, X., Yang, H., Yan, Y., Liu, K., \& Huang, C. (2018). Exploring the effect of social media information quality, source credibility and reputation on informational fit-to-task: Moderating role of focused immersion. Computers in Human Behavior, 79, 227-237. 